2. Митрофанова Д.А. Вокальная фонетика (Итальянский язык). Санкт-Петербург, Санкт-Петербургская государственная консерватория им.Н.А.Римского-Корсакова, 2005.25 с. URL: https://studfile.net/preview/1836416/ (data di riferimento 16.10.2019).

DOI https://doi.org/10.30525/978-9934-26-039-1-40

\title{
НАЙУЖИВАНІШІ СТИЛІСТИЧНІ ЗАСОБИ ХУДОЖНЬОЇ ВИРАЗНОСТІ В ПОЕЗІЇ МАХМУДА КИРИМЛИ (НА ПРИКЛАДІ ПОЕМИ «ЮСУФ І ЗУЛЕЙХА»)
}

\author{
Емірамзаєва Афізе \\ стариий викладач кафедри східної філології
}

Навчально-наукового інституту філологї та журналістики

Таврійського національного університету імені В. І. Вернадського

м. Київ, Украӥна

Як відомо, у художній літературі засоби виразності надають мові яскравості, посилюють її емоційний вплив на читача або слухача. Засоби мовної виразності різноманітні. Розрізняють фонетичні (звукові), лексичні (пов'язані зі словом -лексемою), синтаксичні (пов'язані зі словосполученням і реченням), фразеологічні (фразеологізми) зображальні засоби, тропи (мовні звороти в переносному значенні). Вони використовуються у різних сферах спілкування: у художньому, публіцистичному, розмовному i навіть науковому стилі мовлення. В офіційно-діловому стилі мовлення вони вживаються рідко. Особливу роль засоби виразності відіграють у художньому мовленні допомагають автору створити художній образ, а читачу - увійти в світ художнього твору, розкрити авторський задум [5].

Досліджувана нами поема Махмуда Киримли «Юсуф $i$ Зулейха» датується XIII ст. За лексичним складом, фонетичною системою, граматичною будовою і стилістичними традиціями вона відображає тюркську писемну літературну мову, яка сформувалася на території тогочасного «Дешт-і-Кипчак». Метою нашої роботи $\epsilon$ дослідження засобів художньої виразності в поемі Махмуда Киримли. Об'єкт нашого дослідження - текст твору «Юсуф і Зулейха», а предмет - лексика та вирази цього твору.

Аналізом мови та індивідуального стилю, а саме стилістичних засобів художньої виразності, у класичних творах українських та зарубіжних 156 
поетів і письменників займалися багато дослідників: О. М. Бандура, Марія Моклиця, О. Галич, В. Назарець, С. Васильєв, О.М.Григор'єв, О. Ситник, Н. Танько, С. Скрита та ін. У кримськотатарському літературознавстві та мовознавстві на сьогодні немає цілісних завершених досліджень $з$ цієї теми, чим і зумовлена актуальність нашого дослідження.

У сучасній лінгвістиці склалися чіткі уявлення про сутність звертання як мовної одиниці та його ознаки. Під лексемою «звертання» розуміється слово (або поєднання слів), що є такою конструкцією, яка вживається 3 метою привернути або втримати увагу співрозмовника. У текстах 3 емоційно-експресивним забарвленням головну роль у звертанні відіграє ставлення до адресата мови або характеристика самого промовця. Залежно від того, які засоби художньої виразності вживаються у звертанні, створюються різні стилістичні різновиди цього мовного жанру [4, c. 169].

Художні тексти містять велику різноманітність тропів і стилістичних фігур у формах звертання. Найбільш поширеними фігурами мови, які вживаються в жанрі звертання, є: метафора, епітет, анафора, градачія, інверсія, риторичне запитання, епіфора та ін. [4, с. 169]. Кількість і характер тропів залежать від творчого методу і стилю письменника. Аналіз літературознавчих джерел засвідчив, що вчені по-різному визначають види тропів. Наприклад, О. Бандура розрізняє тропи першої групи (епітет, порівняння, метафора, уособлення, алегорія, символ), та другої групи (метонімія, синекдоха, гіпербола, літота, іронія, оксиморон, перифраз, евфемізм) [1].

Важливим засобом мовленнєвого оформлення літературного твору $є$ його синтаксис, поетичний синтаксис, що враховує таку будову речень і словосполучень, яка впливає на характер інтонацій, темп і паузи при читанні, на зміст і емоційність. Елементами поетичного синтаксису насамперед вважають так звані «стилістичні фігури». Це особливі лексичні конструкції, що відхиляються від певних синтаксичних норм i дають оригінальну форму для образного представлення художнього матеріалу. Слово у стилістичній фігурі, на відміну від тропа, не обов'язково виступає у переносному значенні [6]. Значне логічне, емоційне та експресивне навантаження у виразі, не беручи до уваги лексичне значення складових речення, мають лексико-синтаксичні стилістичні засоби. Одним із таких засобів є градація. У творі «Юсуф і Зулейха» М. Киримли багато разів використав стилістичну фігуру градація (qarşı vardı, ağladı, iñledi) [2, c. 24; 3, c. 59; 7]. Наприклад: Caire qarşı vardı - Служниия підійшла до нього; Başını açı ağladı - 
Відкривши голову, плакала; Ah idüben iñledi - Ридма ридала. Далі автор знову використав стилістичну фігуру градація: vardl, uyudl, kördi, sevinü - пішов, ліг спати, побачив (гарний сон), зрадів, satasin, batasin, etesin, şad ölü- віддаси, погрузнеш, зробиш, станеш радісним $[2$, c. $44-45 ; 3$, с. $62 ; 7]$.

Крім стилістичних фігур, автор використовує різні тропи (гіперболу, метафору тощо): Beni qatt ăglattin - I мене змусив сильно страждати [2, с. $24 ; 3$, с. $59 ; 7]$. У наведеному прикладі бачимо певну гіперболізацію: qattı ăglattin - змусив твердо (сильно) плакати. У тексті також вживано багато метафор. Наприклад: метафора уӥ̈zӥn topră̆a urdı - вклонилася до землі обличчям, що має смислове навантаження «вклонилася Богу». Anin qatından alğgl - навіть із пам'яті забери. Slğmaz içine haber - новина, яка не може розміститися в душі [2, с. 25-29; 3, с. 59-61; 7]. Звичайно це вживається не в прямому значенні. Головний герой розповів розтлумачений батьком свій сон тітці та попросив ії нікому не розказувати. Цій новині вона дуже зраділа та не могла знайти собі місця, адже сон віщує про те, що Юсуф стане правителем. Далі описуючи братів Юсуфа, єгипетського торгівця, автор знову вдається до використання метафори: ep qarardt içleri - в душі все почорніло [2, с. 29; 3 , с. 61; 7] , тобто почувши новину, що Юсуф обраний, братам від заздрощів стало погано. Наприклад: Dilinden yalan kelmez - з язика ніколи не зірветься брехня, тобто дуже чесна людина, kün indigin - сонце сіло, тобто автор має на увазі, що наш персонаж, торговець, пережив скрутні часи $[2$, с. $44-45 ; 3$, с. $62 ; 7]$.

Всі кольоропозначення в художньому тексті є епітетами. У поемі ми бачимо яскраві приклади епітетів: qıaruban kün doğdı - червоне сонце народилося, qara bulut qopt - зірвалася темна хмара. Далі в поемі за допомогою метафори $\boldsymbol{B u}$ belâ bize geldi - нас наздогнало нещастя автор підкреслює, дає настанову, що до Бога потрібно звертатися постійно. Дослівно цей вираз перекладається як «Прийшла до нас біда»[2, с. 53-54; 3 , с. 65-66; 7].

Також ми можемо спостерігати, як автор при описі вроди головної героїні Зулейхи в одному чотиривірші вживає два тропи: enimem i порівняння. Наприклад: güneşe beñzer yӥzӥ - обличчям схожа на сонце тут автор порівнює обличчя дівчини із сонцем, uçmaq qızı slfatlu - зовні легка, наче літає. Поет показує, що дівчина зовні дуже тендітна [2, с. 65; 3 , с. 67; 7]. Можна також виокремити певний символ, літературнохудожній образ: güneş - сонще, що символізує світло, втілення добра.

Образ, який створюється тропом, будується на порівнянні (явному або прихованому), що народжує нове, переносне, з іншими значеннями 
слова або поєднання слів. У нашому тексті у 203-му та 224-му чотиривіршах бачимо опис головного героя: Hubluğına imrenü Захоплюючись (засліплений) красою; Ya Beșir! Haza ̆̆ulâm - O щастя моє! Цей хлопець; Sanasiñ bedr-i tamam - Ти переконаєшся, що станом бездоганний він; Sureti cedd-ül enam [4, с. 45-47; 5, с. 62-63; 11]. У наступних прикладах автор застосовує такі стилістичні фігури, як риторичне запитання та інверсію, повтори тощо. Наприклад: «- Ayit, qandasıñ? - dedi. - Qıldıñ sen beni delü» [2, с. 65-67; 3, с. 67; 7]. Крім того, в досліджуваному тексті є фігури повтору, а саме звукові, які в свою чергу поділяються на: алітеращію, асонанс, риму (повтор звуків наприкінці віршових рядків або їхніх складових частин). Це можна побачити в усіх прикладах, наведених у нашій роботі.

Отже, можна зробити висновок, що аналіз стилістичних елементів у поемі «Юсуф i Зулейха» М. Киримли показав, що образність i експресивність в його художньому творі спирається на індивідуальні тропи в поєднанні з фігурами. Слід наголосити на особливій ролі метафор, епітетів, які збагатили твір, і на стилістичній фігурі градації у створенні інтонації невдоволення, обурення, а також на використанні інверсії. Варто відзначити майстерне застосування письменником риторичних фігур і фігур повтору.

Використання мовних засобів виразності демонструє добре авторське володіння мови та знання ії виразних засобів, свідчить про освіченість, словниковий запас, образне мислення письменника.

\section{Література:}

1. Бандура О.М. Мова художнього твору : [нарис] / О.М. Бандура. Київ : Дніпро, 1964. 121 с.

2. Киримли M. Юсуф ве Зулейха: тарихий дестан неширге азырлагъан Фазыл Р. [арап уруфатындан латинге транслитерация япкъан Къонуратли К.]. Симферополь : КъДжИ «Къырымдевокъувпеднешир» нешрияты, 2013. $220 \mathrm{c}$.

3. Кокиева $A$. Интегрирленген курс «Къырымтатар ве джиан эдебияты» 9 сыныф, окъутув къырымтатар тилинде алып барылгъан умумтасиль мектеплери ичюн дерслик. Черновцы : Букрек нешрият эви, 2017. $288 \mathrm{c}$.

4. Олесик A.B. Средства художественной выразительности в формулах обращений / А.В. Олесик, Л.С. Моисеева Социальноэкономические явления и прочессы. 2013. № 3(049). С. 169-173.

5. Средства художественной выразительности. URL: http:// russkiy155.blogspot.com/p/blog-page_18.html (дата звернення: 26.01.2021) 
6. Стилістичні фігури у мові літературного твору. URL: https://studfile.net/preview/7163442/page:8/ (дата звернення: 27.01.2021)

7. Kirimli M. Yusuf ile Züleyha / Mahmud Kirimli, neşirge azirlayan I.H. Ertaylan; İstanbul Üniversitesi Edebiyat Fakültesi yainları. - № 860. İstanbul, 1960. - $122 \mathrm{~s}$.

DOI https://doi.org/10.30525/978-9934-26-039-1-41

\title{
LABELING TACTICS AS A LINGUISTIC MARKER OF DONALD TRUMP'S CONCEPTUAL STYLE
}

\author{
Yenikeyev D. S. \\ Postgraduate Student \\ Zaporizhzhia National University \\ Zaporizhzhia, Ukraine
}

Politicians and their speeches are always under the scrutiny of the public. In their speeches, politicians try to represent themselves as positively as possible and focus on the negative features of their competitors with the help of various language manipulations.

As the researchers define this phenomenon, «linguistic manipulation is a kind of manipulative influence carried out through the skillful use of certain language resources for the purpose of latent influence on the cognitive and behavioral activity of the addressee» [4, p. 25]. One such technique of linguistic manipulation is «labeling», which is aimed at using language means for «attaching» some kind of attitude towards opponents.

This technique is frequently used by Donald Trump. As a former successful media person, he is well aware of what this action is capable of. The technique of sticking labels is «the use of negative words in order to discredit ideas, plans of the individual, to cause a feeling of prejudice, fear, hatred, without resorting to an objective assessment or analysis» [1, p. 42]. Therefore, we can see that labels are subjective statements, and their purpose is to highlight negative features of a person.

The former US president is famous for his great love for the social network Twitter. In his tweets, he was not shy about naming and describing opponents. Negative nomination is a "publicistic label that «condenses» in itself a negative emotional charge, which has a powerful effect on the reader's 